\title{
Funding Effectiveness of TVET for Decent Employment and Inclusive Growth in Nigeria with Perspectives from China
}

\author{
Adekunle Osidipe \\ China Africa Education Cooperation Research Center, Institute of African Studies, Zhejiang Normal University, \\ 688, Yingbin Avenue, Jinhua, Zhejiang Province, China 321004
}

\begin{abstract}
In the midst of abundant human and natural resources, Nigeria continues to be beleaguered with persistent unemployment, low productivity and poverty. Key sectors of Nigeria's economy which are expected to drive growth, such as infrastructure, retail and manufacturing services require services of personnel with post-basic and technical and vocational skills, but these skills are being produced in small numbers and with poor quality. The country has a vibrant and economically viable youth population that needs to be engaged in productive ventures to help make significant contributions to the national development of Africa's largest economy and overcome their vulnerability to anti-social or anti-government activities against the security and peace of the country. This study explores the context of TVET in Nigeria against the background of the effectiveness of funding provision to TVET in the country. The study identified significant demand for TVET provision in Nigeria based on the analysis of key indicators of the context within which TVET operates. Also, the study showed that though the government has made funding available to education and TVET in Nigeria, the distribution of funds in expenditure contradicts effective utilization of available limited resources and puts forward suggestions on effective funding of TVET in Nigeria by drawing on the successful experience of China. Taking China's successful TVET funding mechanism as example, the study explores China's funding policies related to TVET and identify key factors for TVE's success in China in the face of global trends and provides a new perspective for TVET research from the Chinese model and the theory behind it that could be adopted in the utilization of limited public funding in Nigeria for effective TVET delivery in the country.
\end{abstract}

Keywords: Funding; TVET; Employment; Nigeria; China

DOI: $10.7176 / \mathrm{JEP} / 10-36-06$

Publication date: December $31^{\text {st }} 2019$

\section{Introduction}

After Nigeria's independence in 1960 and up till the late 1970s, TVET was a popular option in meeting the expected skill requirements of industrialization and ease the problem of unemployment among the young school graduates. However, sequel to the concerns raised by the World Bank's rate of returns studies that showed higher returns on investment in general education than vocational education, there was a drastic shift of interest to the funding of general basic education at the expense of funding of TVET. During the period between 1980s and 1990 s, the World Bank's lending for TVET to the African region dropped sharply more than $40 \%$, compared to other parts of the world (Bennell \& Segerstrom, 1998a). This affected the bank's financed education training projects and undermined external support for TVET. From this point, the attractiveness of TVET began to wane as education provision in Nigeria largely slanted towards the general pathway and TVET pathway is considered as option for the low achievers. In the midst of abundant human and natural resources, Nigeria continues to be beleaguered with persistent unemployment, low productivity and poverty. Key sectors of Nigeria's economy which are expected to drive growth, such as infrastructure, retail and manufacturing services require services of personnel with post-basic and technical and vocational skills, but these skills are being produced in small numbers and with poor quality. The country has a vibrant and economically viable youth population that needs to be engaged in productive ventures to help make significant contributions to the national development of Africa's largest economy and overcome their vulnerability to anti-social or anti-government activities against the security and peace of the country. The challenge is that they need access to quality education to cultivate skills needed for them to fit effectively into the world of work or create jobs (UNESCO, 2012). Nigeria has consistently occupied the lower rungs of the Global Competitive Index ladder as a result of low productivity and over reliance on resource export. The country's economic mainstay is crude oil export coupled with exports of other primary commodities without any additional processing prior to export. A large number of the youth population are engaged in informal employment as a result of lack of access to formal employment. It has been projected that Nigeria will need over 40 million jobs between 2010 and 2030, and education and skills development are vital in the production of these jobs (IBRD \& World Bank, 2015). Unemployment and underemployment among the educated population due to lack of requisite skills for the labour market is widespread. Also, it has been observed that some job seekers either under-qualified or over-qualified for the job they seek. A signal that there exists weakness in the skills development systems in the country. Nigeria has an economically active working age population over $50 \%$ of the national population, with pronounced youth unemployment among secondary school 
age students (National Bureau of Statistics, 2016a).

\section{The Context of TVET In Nigeria}

TVET context includes the consideration of information about some features of the society and the economy within which TVET system operates as these features have significant likelihood to shape the performance of TVET in any society. According to Guo \& Lamb (2010) countries with high levels of GDP are likely to have more money to spend or invest in education than less wealthy countries, just like countries with high levels of higher education, especially at the upper secondary level and above will have upper performance in education and training than nations that do not. TVET delivery in Nigeria is considered in relation to the following features of the context indicator adapted from an earlier study on international comparison of TVET in China by Guo and Lamb (2010). These features include the educational attainment of adult population, the GDP per capita, labour force participation rate by educational attainment as well as, unemployment and under employment rate by educational attainment. Some other features not in the earlier study of Guo \& Lamb, but within the parameters of the context indicators were included (under employment by educational attainment) to enable further understanding of the context of TVET delivery in Nigeria.

\subsection{Educational Attainment of the Adult Population}

Educational attainment of the adult population provides information on the current levels of educational attainment in the country's labour force. It has been observed that nations with well-educated population marked by high literacy levels, high levels of upper secondary school completion and strong levels of university (postsecondary) education participation are likely to display markedly different patterns of performance in terms of education and training than nations with populations with low levels of literacy and low levels of transition from lower education levels to higher education (OECD, 2004). The educational attainment of the adult population of a country is significant in measuring the level of human capital development and changes in the levels of educational attainment of the adult population have significant implications in the role and development of TVET (Guo \& Lamb, 2010). This is due to the fact that the level of educational attainment depicts the levels of skills available in the labour force and whether the available skills in the labour force are likely to meet the demands of the labour market. The educational attainment plays significant roles in determining the decisions of prospective industries, firms seeking expansion of their production activities or investors to locate their business interests in a country because of the level of skills available for them there.

With the constant changes in globalization and advancement in technology, a country's human capital must adapt to the changes in order to remain relevant and maintain considerable level of competitiveness. The TVET system in the country plays significant role in equipping the manpower with the requisite knowledge, skills and competencies (Guo \& Lamb, 2010). As a developing country striving to transform into an industrialized economy, there is strong clamor for technology transfer from the more technologically advanced countries. However, the transfer of technology requires an availability of knowledgeable, trained, skilled, and competent manpower to be effective (Joshua A. Bello, 2005).

Table 1 shows the educational attainment of the adult population in Nigeria (ages 25-64) for 2003, 2008, 2011 and 2013. The table shows that a very low percentage of the population 25-64 years has attained secondary education, signaling a significant number of the adult population are poorly educated. The table shows that in 2003 , only $7.0 \%$ of the adult population had attained secondary education. Though in 2013 the number has increased to $17.1 \%$, it is still an appalling rate considering the country's need for a skilled workforce. The country will continue to face challenges in the quest for development if the skills supply within the workforce is not improved through the provision of quality education especially TVET.

With many young adults not completing secondary education after completion of basic education, a huge gap exists in meeting the skills requirement of the national labour force. According to the Federal Ministry of Education (2009b), the upper secondary education level in the country is faced with the problem of inadequate enrolment inadequacy of legal backing and absence of quality control organ, low learning outcomes in literacy, numeracy and life skills coupled with extremely low enrolment in Technical and Vocational Educational Institutions. Out of the 10million potential students expected to enroll in upper secondary education in the country in 2009, only 2.8 million (28\%) got enrolled leaving a total of 7.2 million (72\%) out (Federal Ministry of Education Nigeria, 2009b). This huge population left out in transition to upper secondary education are supposed to be absorbed by the technical and vocational colleges representing the secondary technical and vocational institutions in the country. TVET in Nigeria is a part of the secondary education (upper secondary education arm). It is quite revealing that the TVET system has a huge role to play in facilitating the knowledge, skills and competence required for the economic transformation and development in Nigeria. 
Table 1: Percentage of Educational Attainment of the adult Population (25-64) by Age

\begin{tabular}{|c|c|c|c|c|c|c|c|c|c|c|c|c|c|c|c|c|c|c|}
\hline \multirow[t]{3}{*}{ Year } & \multicolumn{9}{|c|}{ Secondary Complete } & \multicolumn{9}{|c|}{ Post-Secondary } \\
\hline & \multicolumn{9}{|c|}{ Age } & \multicolumn{9}{|c|}{ Age } \\
\hline & $\begin{array}{l}25- \\
29\end{array}$ & $\begin{array}{l}30- \\
34\end{array}$ & $\begin{array}{l}35- \\
39\end{array}$ & $\begin{array}{l}40- \\
44\end{array}$ & $\begin{array}{l}45- \\
49\end{array}$ & $\begin{array}{l}50- \\
54\end{array}$ & $\begin{array}{l}55- \\
59\end{array}$ & $\begin{array}{l}60- \\
64\end{array}$ & $\begin{array}{l}25- \\
64\end{array}$ & $\begin{array}{l}25- \\
29\end{array}$ & $\begin{array}{l}30- \\
34\end{array}$ & $\begin{array}{l}35- \\
39\end{array}$ & $\begin{array}{l}40- \\
44\end{array}$ & $\begin{array}{l}45- \\
49\end{array}$ & $\begin{array}{l}50- \\
54\end{array}$ & $\begin{array}{l}55- \\
59\end{array}$ & $\begin{array}{l}60- \\
64\end{array}$ & $\begin{array}{l}25- \\
64\end{array}$ \\
\hline 2003 & 23.1 & 13.9 & 8.3 & 4.3 & 2.8 & 1.6 & 1.4 & 0.9 & 7.0 & 10.3 & 12.1 & 13.5 & 11.8 & 10.5 & 5.7 & 5.6 & 3 & 9.1 \\
\hline 2008 & 26.8 & 23.3 & 21.3 & 18.3 & 14 & 8.3 & 5.9 & 5.7 & 15.5 & 15.4 & 15.6 & 14.3 & 13.5 & 13.3 & 8.7 & 7.2 & 4.9 & 11.6 \\
\hline 2011 & 28.2 & 25.8 & 25.3 & 21.5 & 18.7 & 12.2 & 8.7 & 7.3 & 18.5 & 21.3 & 18.4 & 16.3 & 15.1 & 16.6 & 13.5 & 9.9 & 6 & 14.6 \\
\hline 2013 & 28.2 & 25.2 & 22.4 & 19.6 & 15.9 & 11.6 & 7.5 & 6 & 17.1 & 16.1 & 16.6 & 13.9 & 13.7 & 12.5 & 12.4 & 8.8 & 5.6 & 12.5 \\
\hline
\end{tabular}

Source: (National Bureau of Statistics, 2017)

\subsection{Nigeria's GDP Per Capita in Context}

The GDP per capita is an economic measure of a country's total output and a primary indicator of a country's economic performance as well as an indicator for measuring the standard of living in a country, with higher GDP per capita equating to a higher standard of living. The GDP per capita provides information on the resources available to a country in relation to the size of its population and it is believed that a higher GDP per capita should enable a country to allocate adequate resources for more extensive educational services to the citizens. Also, the GDP per capita can also be used to measure the productivity of a country's workforce, as it measures the total output of goods and services per each member of the workforce in a given nation. Chart 3 shows the GDP per capita of Nigeria, China and India using the Purchasing Power Parities (PPP) rates in order to use an equivalent standard, while eliminating differences in price levels between countries. The choice of China and Nigeria in this context is informed by the fact that the trio are in the same "analytical group" classified by the International Monetary Fund (IMF) as "Emerging Markets and Developing Economies" and are characterized by significantly large populations. It is noteworthy that the difference in GDP per capita among the trio was relatively negligible between the early 90 s and the late end of the $90 \mathrm{~s}$, but this took a new turn as the gap widens and continues to enlarge from the early 2000 s, especially to the disadvantage of Nigeria.

The period between the early and late 90 s was very significant for Nigeria and China in the context of this study, because it was at this period that Nigeria embarked on series of economic reforms that cut down government spending on education, especially technical and vocational education. A decision believed to be informed by the World Bank rate of returns on education report which portrayed TVET as not lucrative for investment in developing countries (Bennell \& Segerstrom, 1998; Psacharopoulos, 1990). The consequences of the economic reforms were not favourable to development of education, especially TVET in Nigeria and several other developing countries that toed the same line (Bennell \& Segerstrom, 1998). China, on the other hand, at the same period was busy making provisions for the development of technical and vocational education to meet the country's desire for industrialization and transformation of the economy. The consequences of both countries' actions could be seen a decade later in the rising gaps in the GDP per capital of both countries as shown in the figure below:

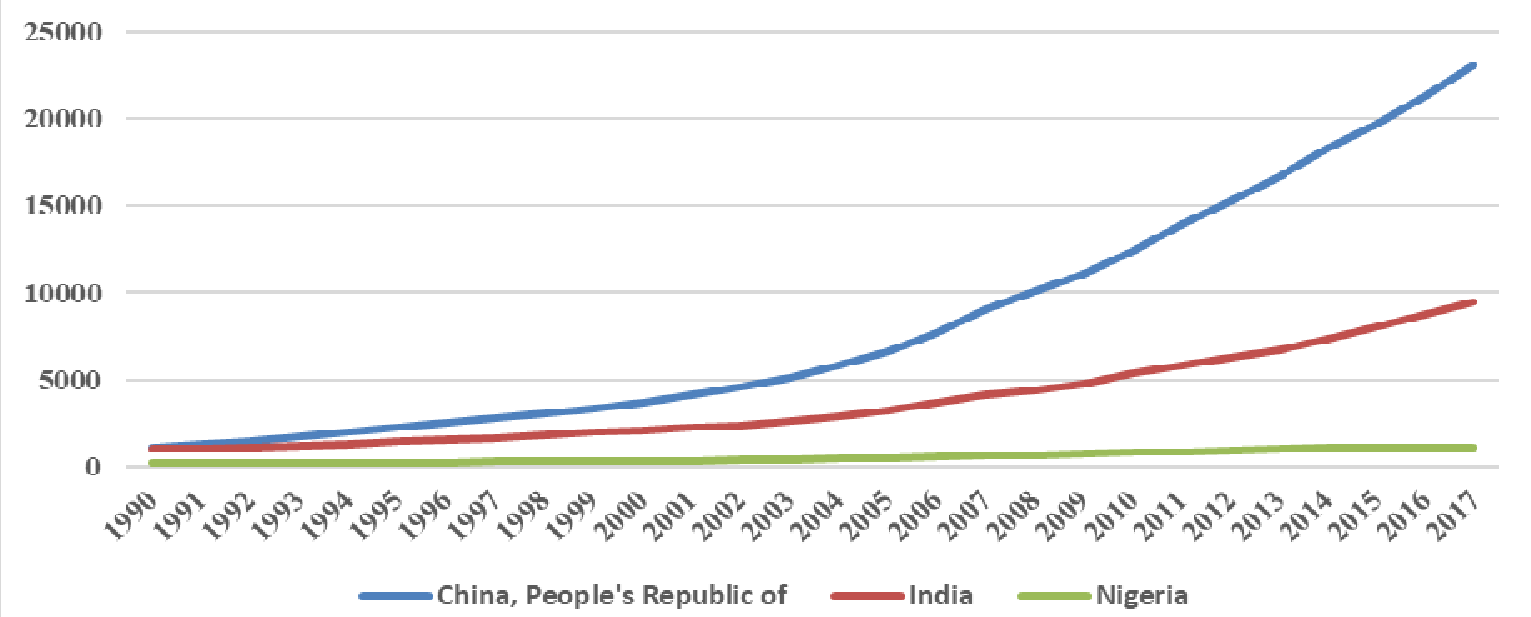

Figure 1: GDP Per Capita, current prices (Purchasing power parity; billions of international dollars), IMF (World Economic Outlook 2017) http://www.imf.org/external/datamapper/NGDPDPC@WEO/NGA/IND/CHN/NGA/IND/CHN?year=2018 
Though low GDP per capita points to less resources for investment in education, especially universal education for critical sectors like technical and vocational education and this has been a major challenge to most developing countries like Nigeria, but it is imperative for the government in Nigeria to invest more in technical and vocational education with the available resources through well-defined policies and informed strategies on funds accumulation for the development of technical and vocational education in the country. On the other hand, when compared to other developing countries in Sub-Sahara Africa, Nigeria's GDP per capita shows the country leading the rest of the Sub-Sahara Africa (Figure 2), depicting that the country has the potential to make provisions for technical and vocational education that will help the country achieve the goal of industrialization and economic transformation.

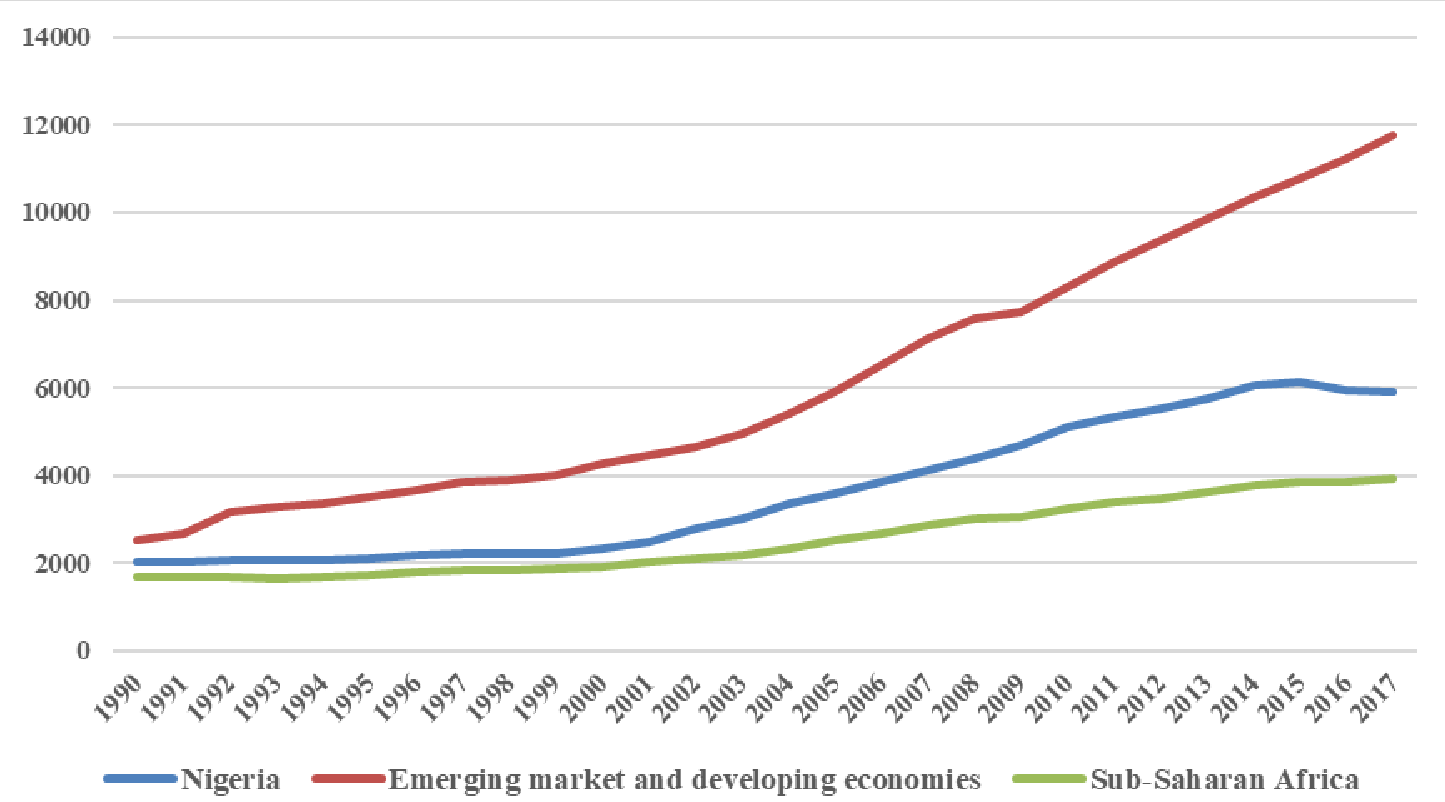

Figure 2: GDP Per Capita, current prices (PPP; billions of international dollars), IMF (World Economic Outlook 2017) http://www.imf.org/external/datamapper/NGDPDPC@,WEO/NGA/EDE/SSA/NGA/EDE/SSA?year=2018

\subsection{Labour Force Participation by Educational Attainment}

The indicator of labour force participation by educational attainment examines the relationship between educational attainment and labour force status in the country. There is high percentage of the labour force who have "Never attended" schools and "secondary" school leavers. The low rate of participation of those with "Postsecondary" education qualification shows a critical challenge of unemployment and underemployment among this group of the population. It also shows the heavy dependence of the labour market on low skilled and less productive work force, which is contributory to the continuous low ranking of the country in the Global Value Chain (GVC) and low Global Competitiveness Index (GCI). It is believed that low skilled workforce work mostly in the informal sector characterized by low productivity, vulnerable working conditions and low wages (AFDB \& OECD, 2008; ILO, 2015; Johansson, Adams, \& Sara Razmara, 2013; NISER, 2009). The high labour force participation rates coupled with the low educational attainment of the working population in Nigeria presents significant prospects for provision of TVET. This comes with likely challenges of making additional provision for continuing education and training. 


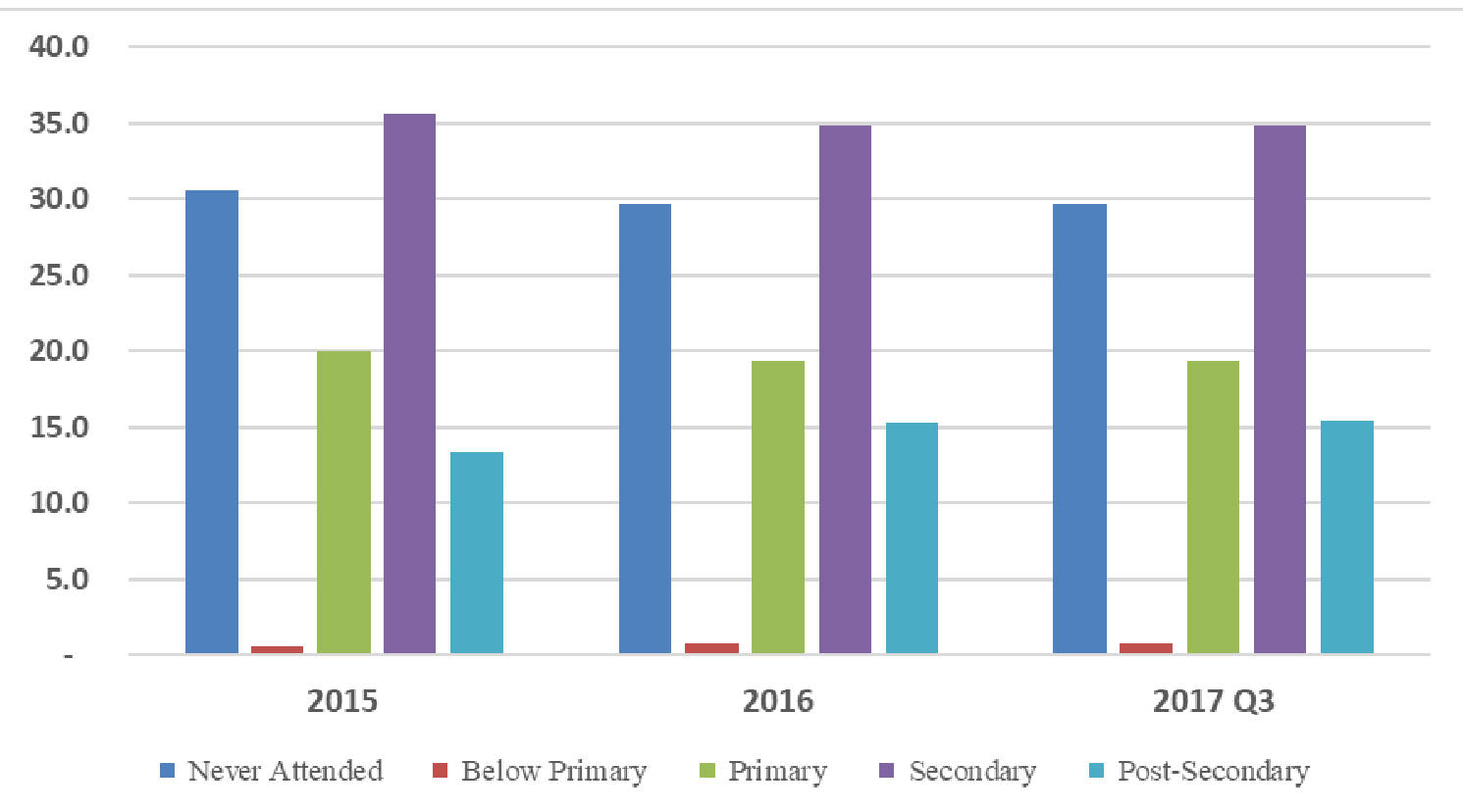

Figure 3: Labour Force Participation Rates by Level of Educational Attainment (National Bureau of Statistics, 2017)

\subsection{Unemployment Rates by Educational Attainment}

The unemployment rates by level of educational attainment indicator is usually adopted in measuring the economic performance of a country. Unemployment rates are useful in measuring the correlation between the output from the education system and the demand for skills in the labour market. There are possibilities for countries to have high labour force participation rates, but demand may be greater than supply and for the rates to mask high levels of unemployment. In this context, those with lower educational qualifications are likely to be at particular risk because of greater vulnerability in a competitive employment market. There is no universal standard definition of unemployment because countries adopt definitions to suit their local priorities. However, virtually all countries use the International Labour Organization (ILO) definition, or a variant of it to compute unemployment. The ILO definition covers persons aged 15-64 who during the reference period (which is usually the week preceding the time the survey is administered) were available for work, actively seeking work, but were unable to find work. The National Bureau of Statistics (NBS) defines unemployment as the proportion of those in the labour force (not in the entire economic active population, nor the entire Nigerian population) who were actively looking for work but could not find work for at least 20 hours during the reference period to the total currently active (labour force) population (National Bureau of Statistics, 2016b). In the Figure below there is a high incidence of unemployment among those with "post-secondary" education when compared with those with lower educational qualifications. The unemployment rate among those with "Post-secondary" education increased by more than double between 2015 and third quarter of 2017. 


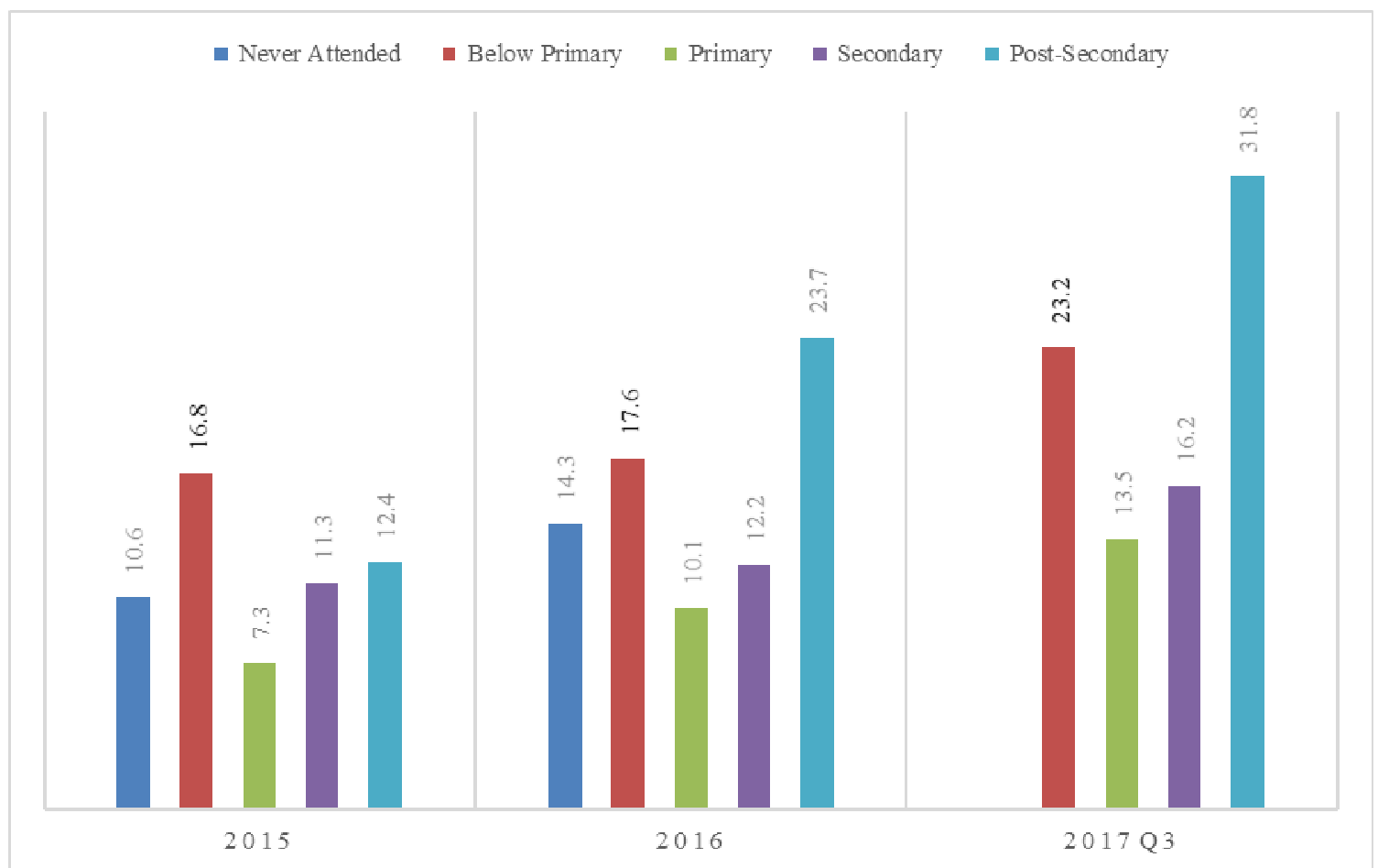

Figure 4: Unemployment Rates By Level Of Educational Attainment (National Bureau of Statistics, 2017)

\subsection{Underemployment Rates by Educational Attainment}

There is high rate of underemployment among those who "Never Attended schools and "Secondary" school graduates. Though this may be generally expected, because this category of labour force is engaged in lowskilled or part-time employment. However, high rate of under-employment among the "Post-Secondary" school certificates holders highlighted the problem of serious unemployment and engagement in low skilled jobs among graduates in the country, as shown in the figure below. This calls for measures that address graduate unemployment phenomenon in the country.

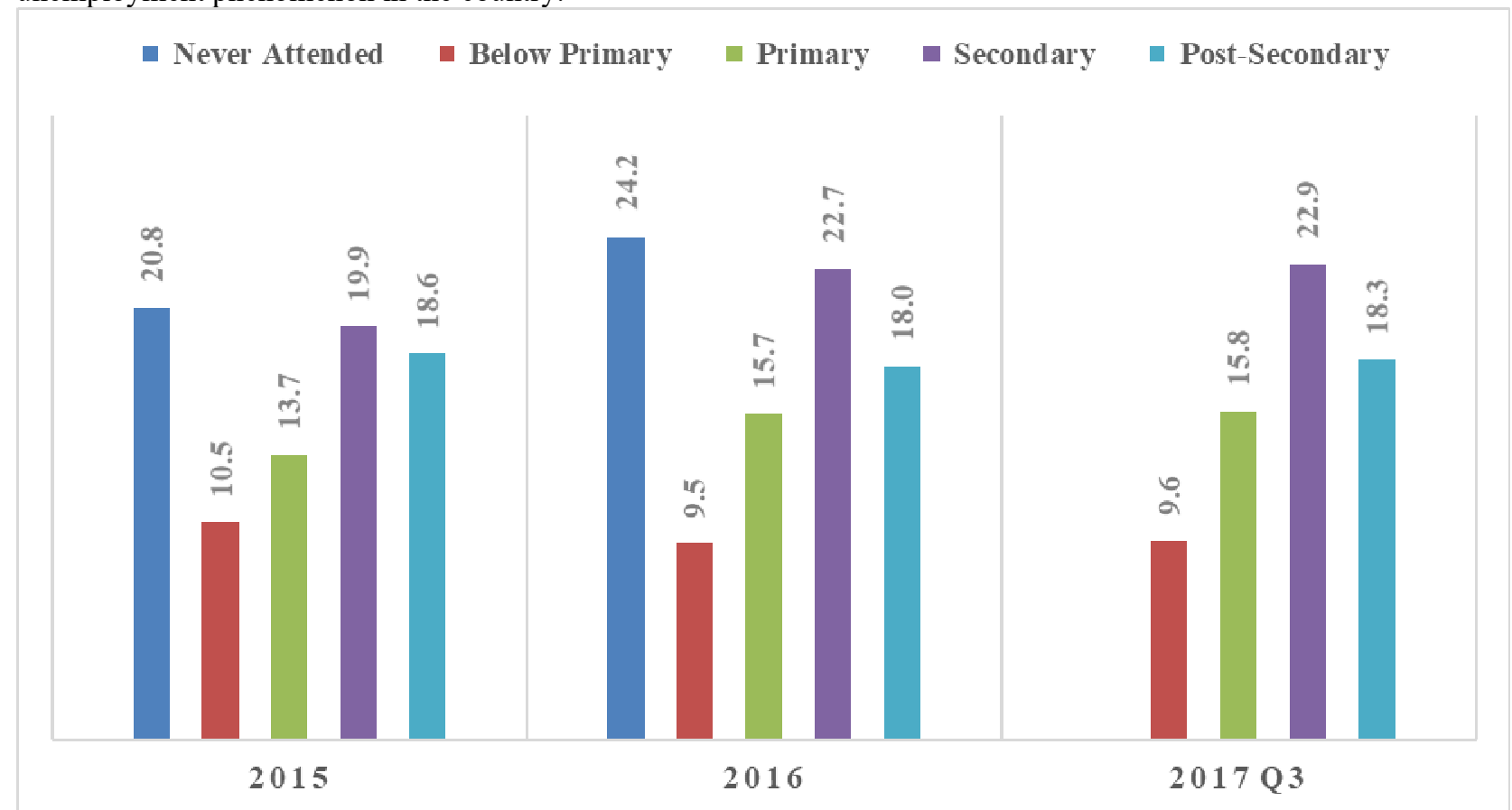

Figure 5: Underemployment Rates By Level Of Educational Attainment, (National Bureau of Statistics, 2017)

3 The Significance of TVET in Promoting Decent Employment in Nigeria

Of what significance is technical and vocational education to employment in a country? It is widely known that 
the quality of a nation's work force is pivotal to economic growth and social development. However, the quality workforce is dependent on labor productivity, or the value of the goods and services produced by a worker and the flexibility of the work force, or the ability of workers to move across sectors of the economy and between industries as the structure of the economy changes (Middleton, Ziderman, \& Adams, 1996). With the increasing changes in global economic environment nations worldwide are giving increasing attention to these factors as they seek to increase the growth of their respective economies and improve the welfare of their citizens in a highly competitive global economy. In Nigeria, the lack of "decent" employment, along with high unemployment and socioeconomic and gender inequalities, has contributed to high poverty levels among the youth and women. The women population suffer disproportionately from unemployment or limited access to jobs, which keeps them under the poverty line. Critical factors behind this worrying trend include the lack of technical and employable skills, lack of information on jobs and access to capital which limit young people's abilities to fully use their skills and make meaningful contributions to the development of their communities. The provision of quality TVET programmes, support for entrepreneurship and creating enabling environment for quality jobs for the youth is crucial for promoting overall economic growth, productivity, innovation and employment (AfDB, 2014).

Studies have established that the higher a country's labor productivity and the more flexible its work force, the better able that country is to acquire and adapt the technology needed to produce better quality goods and services at lower cost and to shift the structure of production to new markets and products. Significant among the factors that increase productivity are the skills and competence of workers at all levels, from senior management to semiskilled operatives in adaptation and use of new technologies, for efficiency and quality of production and maintenance, as well as supervision and training of workers with lesser skills (Radwan \& Pellegrini, 2010). Possession of relevant skills and competence among workers in rural and urban informal sectors also enhances their productivity level in their chosen field of employment. Technical and vocational education (TVET) institutions play an important role in equipping young people to enter the world of work and in improving their employability throughout their careers. The world is daily faced with rising youth unemployment in developed and developing countries with the attendant challenges. The challenge of unemployment globally is further compounded by the inability of young people to attain decent work because they are ill-prepared for the world of work (Dike, 2009; NISER, 2009; Odu, 2010; OECD, 2015; Uddin \& Uddin, 2013) The informal sector and traditional rural sector have remained the predominant sources of employment with vulnerable working conditions. Workers employed in these sectors stands at over 1.44billion worldwide with Sub-Saharan Africa and South-East Asia contributing the largest number with three out of four workers working in vulnerable employment conditions (UNESCO, 2016).

TVET can equip youth with the skills required to access the world of work, including skills for selfemployment. Apart from improving responsiveness to changing skill-demands by companies and communities, increase productivity and increase wage levels, TVET can reduce access barriers to the world of work, for example through work-based learning, and ensuring that skills gained are recognised and certified. The significance of TVET and the world of work also include the provision of skills development opportunities for low-skilled people who are under-employed or unemployed, out-of- school youth and individuals not in education, employment and training (NEETs) (UNESCO, 2016). Maclean and Wilson (Maclean \& Wilson, 2009) asserted that TVET is a crucial platform for the acquisition of skills and knowledge for employment and sustainable livelihood. TVE is considered to provide the needed employable skills and attitudes necessary for effective performance in the workplace. On the global scale, major reforms are being carried out in different countries because of the increasing recognition of the crucial role of higher technical skills play in enhancing competitiveness, social inclusion, decent employment and poverty reduction. Billet (2011, pp. 17-18) posited that educational provisions should be concerned with finding ways of assisting individuals in identifying the occupation to which they are suited, the initial development of capacities required for that occupation, and then, the refinement of those capacities and their ongoing development throughout working lives and in ways to sustain employability. Billet further identified four purposes that are central to TVET as educational provisions that focus on

(i) the preparation for working life including informing individuals about their selection of an occupation;

(ii) the initial preparation of individuals for working life, including developing the capacities to practice their selected occupations;

(iii) the ongoing development of individuals throughout their working life as the requirements for performance of work transform over time; and

(iv) provisions of educational experiences supporting transitions from one occupation to another as individuals either elect or are forced to change occupations across their working lives.

From the views of scholars and international bodies on the relationship between TVET and employment, it could be seen that developing relevant skills facilitates the application of new technologies, increases 
individuals' employability and enterprises' productivity and competitiveness. However, TVET by itself is not sufficient. It needs to form part of integrated policies directed at economic growth and employment to be fully effective (AFDB \& OECD, 2008; ILO, 2015). There is the need for the economy to generate sufficient decent employment opportunities, but this is not the case in most developing countries, where most of new work opportunities are found in self-employment and work in the informal economy rather than in formal employment (Kenneth King \& Robert Palmer, 2010). This calls for tying the TVET programmes to specific national development programmes as was the case in China (Guo \& Lamb, 2010), and policy makers need to make provision for policies that create enabling environment for graduates of skills training programmes to start up and engage in businesses in the informal sector as well as give pre-training and post-training supports to trainees while special attention should be given to support women in equal access to training and employment opportunities (Kenneth King \& Robert Palmer, 2010).

\section{Funding and Effective TVET Delivery}

Adequate funding is crucial for quality TVET provision. Funding policy, and how such policy is implemented, equally vary from country to country according to national economic priorities. Policies and Mechanisms of funding include public funding, training fees, private funding, international assistance, industry support and funding support from other non-governmental organizations (Afeti, 2009; Atchoarena, 2009). The principal source of funding for TVET in most countries is government, with supplementary support from a range of organizations, bodies and individuals. Levies imposed on enterprises (effectively a form of taxation) are a further option for generating funds for TVET support and promotion of skills development (Afeti, 2009). Training funds outside of normal government allocation may be supported by means such as levies on organizations, businesses or industries and by donations from one source or another (Johanson, 2009). Some TVET policies provide for a dual system of TVET delivery in which funding is a joint responsibility of government and private enterprise. The government takes care of the school costs while the participating enterprise caters for the practical aspect of the training (UNESCO-IIEP, 1996). Quality TVET is the bedrock of all social and economic development, and adequate funding is the foundation on which it relies. The level of adequate funding available for TVET determines the level to which adequate qualified staff, teaching and learning materials will be provided. TVET relies significantly on teaching and learning equipment which are often very expensive. The lack of funding for the purchase of up-to-date teaching and learning equipment is a major constraint inhibiting the training of skilled and employable graduates due (Kingombe, 2012; Oketch, 2014).

\section{TVET Funding in Nigeria}

Nigeria's constitution places education on the concurrent list, which means that both the federal and state governments can make legislation on the planning, organization and management of education, but the Federal Government is empowered to regulate all sectors of education, make policy and ensure quality control. The responsibility for educational institutions is shared between Federal, State, local government, communities and private organizations. The Federal Ministry of Education has the major responsibility for education, but other Ministries also play significant roles in achieving the national goals for education. For example, publicity for educational policies and programmes is the responsibility of the Federal Ministry of Information while the Ministry of Women's affairs and Social Welfare together with the State Commission for Women also play a role in promoting the education of women and girls. The education ministries in the States are responsible for the development and implementation of educational policies, management and supervision of educational institutions in their respective states. The ministries are responsible for maintaining all public elementary and secondary schools in the states, including teachers' recruitment, appointment, promotion and discipline; and provision of guidelines on the establishment of new schools and training and re-training of teaching and nonteaching staff. The ministries of education at the state level carry out their functions through a number of agencies. For instance, the State Universal Basic Education Board (SUBEB) is responsible for the management of basic education, while the Teaching Service Commission takes charge of senior secondary education at the state level.

Statutory Commissions operating as parastatals of the Federal Ministry of Education oversee the tertiary education sector. For instance, universities are supervised by the National Universities Commission (NUC), the colleges of education are supervised by the National Commission for Colleges of Education (NCCE), while the National Board for Technical Education (NBTE) oversees polytechnic education. These commissions are responsible for policy decisions affecting institutions under their supervision, maintenance of standards through accreditation of courses, distribution and monitoring of government funding, appointment of members of governing councils, and the day- to-day running of the institutions. School-based TVET delivery in Nigeria has consistently been overlooked by governments at all levels in Nigeria leading to its current worrisome state. Nigeria has all the potential to become a leading global economy but requires the proper harnessing of her available abundant human and material resources to accomplish this. A transformation of the lip service 
commitment of government to TVET (Inyiagu, 2014; Obanya, 1996) will make significant impact in alleviating the current large-scale mass unemployment of youth, poverty and insecurity triggered by unemployment-induced poverty. The consequence of neglect of TVET over the years are seen in the country with weak infrastructure, capital flight due to cost of bringing in foreign workers to do works that could have been done by locally trained workers, food insecurity and reliance on food importation even when the country has ample land available for agriculture enough to feed the nation and export to other countries.

While it is the intention of the National Policy on Education to make many students be technologically literate through the effective delivery of TVET, there are areas of concern like the desertion of technical and vocational education by students after the completion of Junior Secondary School, and the grossly inadequate provision of enough human and material resources at virtually all levels of technical and vocational education in the country (Federal Ministry of Education Nigeria, 2005). The National Board for Technical Education identified unbridled preference for university education by learners and their guardians due to lack of awareness on the importance of Technical and vocational education. Apart from this, the educational institutions place less emphasis on the manpower need of the industry which causes proliferation of mainly academic programmes. The national regulatory body also identified poor national manpower planning and implementation resulting in insufficient data on skill gaps, and type of curriculum educational institutions should focus on as well as assessment and evaluation processes in TVET institutions, which has remained largely academicee, despite global trend towards industry-based standard.

A burning issue surrounding TVET delivery is funding. There are several national issues demanding for government's attention in terms of provision of finance, and many find it questionable why the government would be required to allocate funds to TVET instead of other sectors like health or housing. In a three-year rolling plan designed to ensure increased funding for education, the Federal Ministry of Education $(2007$, p. 28) made proposal seeking an increase in Government spending on education from $8 \%$ of budget in 2007 to $26 \%$ in the following phases:

$201015 \%$

$201520 \%$

$202026 \%$

as well as an increase in education spending from less than 5\% of GDP in 2007 to at least $10 \%$ by 2020 in the following phases:

$20106 \%$

$20158 \%$

$202010 \%$

The reality however is that the proposal has not been transformed into reality. Investment of government or the private sector in TVET will yield sufficient employable knowledgeable and skilled workforce, high level of productivity and economic growth. Not only these, it will also engender the lifting of several people out of poverty and vulnerability, enable enterprises meet their production targets as well as enable the country to the national development objectives including international competitiveness. Technical and vocational education is severely underfunded in Nigeria (Federal Minstry of Education Nigeria, 2005). Insufficient funding by the government is a major factor inhibiting the implementation of technical and vocational education programme in the country. The level of funding available for technical and vocational education impacts on the quantity and quality of facilities and equipment made available to effectively train technical education students (Okoye \& Udoudo, 2015). As a result of inadequate funding, many technical and vocational institutions in the country battle with non-availability of functional workshop, inadequate instructional materials, and absence of electricity for operating the workshop equipment. Odu (2010) posited that many administrators of TVET at the policy making level in Nigeria are not trained in vocational technical education hence, they have little understanding of the needs of the TVET when it comes to distribution of funds. This explains why technical and vocational education is grossly under-funded. The under-funding in turn affects the supply of modern facilities and equipment needed for teaching and learning. The Education Trust Fund (ETF), is an agency of government set up to provide funding for innovative and technology-based research due to the reality of paucity of funding for specialized education. (Gabadeen \& Raimi, 2012; Idris et al., 2012). Despite the ETF/TETFUND intervention, funding earmarked for TVET is still insufficient and inadequate (Ladipo, Akhuemonkhan, \& Raimi, 2013).

The lack of adequate funding relative to the increasing surge in student population in Secondary and Technical/Vocational Schools has resulted in limited access and equity, inability to attain set standards, disproportionate student-teacher ratio, among others. These, in turn, have led to steady decline in the quality of curriculum delivery and over-stretching of available facilities and infrastructure. Expenditures on Post Basic education in public schools are essentially the responsibility of the State and Federal government for unity schools. As a result, the information base is very weak for debates on fundamental issues such as the adequacy of funding for post basic education in general and at both level, the sources of funding, the efficiency and equity of the use of public funds, costs of system expansion and the appropriate mix of public and private (household) 
expenditures. The main problem lies in gathering and aggregating information on state government expenditures (Federal Ministry of Education Nigeria, 2009a).

The major problems in collecting data on post basic educational expenditures occur at the level of the state governments. It is difficult to collect funding data in 36 states and the Federal Capital Territory due to the problem of fiscal federalism. Also, there is no constitutional requirement for states to report budgetary information to the Federal government, and consequently there is no such reporting. At the same time, the level of monitoring of state government expenditure has diminished and there is no single location at a Federal institution, or elsewhere, at which the necessary information (annual budget books or audits) is held, let alone collated and analyzed. Within states, departments of post basic education do not control the budgets of post basic education such as vocational and technical institutions, therefore, any detailed expenditure data (beyond a single budget line) by state governments on post basic education institutions requires visits to each institution. On the other hand, lots of post basic education expenditures are not included in the budgets of Education Departments and sources of public expenditure outside of departmental budgets exist, like the Education Tax Fund (ETF) (Federal Ministry of Education Nigeria, 2009a).

The fragmentation of funding sources affects the use of resources within post basic education. First, it is difficult to ascertain (a) overall public spending for post education, (b) spending at state and federal level of post basic education, and (c) functions of different government agencies. Monitoring, regulation, and policy making are very challenging. Second, different funding sources bring different incentives to the table, making it difficult to ensure efficiency and equity in public spending at post basic level. Third, administrative costs are high because different sources operate as stand-alone, vertical funding sources. Fourth, multiple sources are unpredictable, making it difficult to ensure sustained financing for medium-term strategies at the state level. Finally, fragmentation without effective coordination compromises the effectiveness of the budget as a tool for achieving accountability. The government budgetary allocation to education is shared among the agencies and parastatals of the government as follows:

Ministry of Education

Universities

Polytechnics

Colleges of education

Government colleges

Technical schools

The main components of the budgetary allocation include statutory transfers (for the Universal Basic Education-UBE), recurrent expenditure (spending by the ministries, departments and agencies of government on salaries, pensions and overheads) and capital expenditure (spending on provision of infrastructure like road, water and electricity, educational services and so on) released to the government ministry/department or agency. Poor Financing of Education is a major problem in Nigeria. Education at all levels is poorly funded by the various tiers of government. Key officials in the Ministries of Education in both Federal and State levels are of the view that though the basic education is well funded but most of the budget is spent on overheads. Consequently, funds hardly get to the school level, and the impacts are not felt. In a country where expenditure on social sectors for poverty reduction is not general practice, social expenditure (including expenditure on Education) has declined between 2005 and 2010, and expenditure it is also far below the requirements of the sector. In a period of six consecutive years, the country's budget for education was consistently below $4 \%$ of her GDP as shown below:

Table 2: Nigeria's Education Spending (2005-2010)

\begin{tabular}{|l|l|l|l|l|l|l|}
\hline Year & 2005 & 2006 & 2007 & 2008 & 2009 & 2010 \\
\hline Education Budget (\%GDP) & $3.3 \%$ & $3.5 \%$ & $3.6 \%$ & $3.6 \%$ & $3.6 \%$ & $3.2 \%$ \\
\hline Education Expenditure (\%) expenditure of all budget & $11.4 \%$ & $13.1 \%$ & $12.0 \%$ & $12.3 \%$ & $11.8 \%$ & $9.5 \%$ \\
\hline
\end{tabular}

Source: Government Spending Data, 2005-2010 cited in UNICEF. (2012). Global Initiative on Out-of-School Children - Nigeria Country Study, (March 2012).

A recommendation of the United Nations Development Programme (UNDP) stipulates that $70 \%$ of national budget be allocated to capital expenditure while $30 \%$ be allocated to recurrent expenditure, however, that has never been the case in Nigeria where recurrent expenditure takes more than $70 \%$ of national budget, same thing that reflects in the allocation in the education sector. More fund is allocated for payment of salaries, pensions and overheads signaling a huge payroll due to large number of personnel employed. However, the country is still in dire need of qualified teachers in all the sectors of education, especially at the post-basic level TVET stream. Though the government financial allocation to education as percentage of total budget has increased compared to previous years, the distribution of expenditure gives serious cause for concern. The government's recurrent expenditure consistently far outweighs the capital expenditure which implies that funds for critical facilities required in educational institutions, especially TVET which is capital intensive, are not provided for due to limited funding. A major problem facing TVET in the country is the dearth of equipment needed for practical 
teaching and learning activities, poor or non-existing teacher training and development programmes due to inadequate funding. The budgetary allocation of government to education between 2005 and 2014 as shown in the table below gives a clear picture of the cause of inadequate provision of requisite facilities in TVET institutions which also makes TVET unattractive to learners.

Table 3: Education Budgetary Allocation (2005-2014)

\begin{tabular}{|l|c|c|c|c|c|c|}
\hline Year & Recurrent & Capital & UBEC & Total & \multicolumn{1}{c|}{ Total Budget } \\
$\begin{array}{c}\% \text { of } \\
\text { Total } \\
\text { Budget }\end{array}$ \\
\hline $\mathbf{2 0 0 5}$ & $92,594,737,799$ & $27,440,790,000$ & $27,800,000,000$ & $147,835,522,799$ & $1,799,938,243,138$ & 8.21 \\
\hline $\mathbf{2 0 0 6}$ & $129,421,908,835$ & $35,791,763,831$ & $30,480,000,000$ & $195,693,672,666$ & $1,876,302,363,351$ & 10.43 \\
\hline $\mathbf{2 0 0 7}$ & $137,478,261,081$ & $48,293,513,848$ & $35,300,000,000$ & $221,071,774,929$ & $2,266,394,423,477$ & 9.75 \\
\hline $\mathbf{2 0 0 8}$ & $162,694,071,909$ & $47,750,746,670$ & $39,700,000,000$ & $250,144,818,579$ & $2,492,076,718,937$ & 10.04 \\
\hline $\mathbf{2 0 0 9}$ & $183,014,340,686$ & $33,625,096,425$ & $35,565,376,384$ & $252,204,813,495$ & $2,870,510,042,679$ & 8.79 \\
\hline $\mathbf{2 0 1 0}$ & $198,084,948,657$ & $97,208,440,839$ & $44,341,401,504$ & $339,634,791,000$ & $4,608,616,278,213$ & 7.37 \\
\hline $\mathbf{2 0 1 1}$ & $304,392,631,774$ & $35,088,896,911$ & $54,328,643,090$ & $393,810,171,775$ & $4,226,191,559,259$ & 9.32 \\
\hline $\mathbf{2 0 1 3}$ & $345,091,448,178$ & $55,056,589,805$ & $68,237,452,545$ & $468,385,490,528$ & $4,749,100,821,170$ & 9.86 \\
\hline $\mathbf{2 0 1 4}$ & $360,822,928,272$ & $71,937,785,489$ & $76,279,000,000$ & $509,039,713,761$ & $4,987,220,425,601$ & 10.21 \\
\hline
\end{tabular}

Source: Author's Collation of Budget information from Ministry of Budget and National Planning, Nigeria

\section{Funding of TVET Delivery in China}

The bulk of TVET financing in China rests on the local government which can be township or county government. Only higher education is financed and managed by central/provincial government. In China, the 1996 Vocational Education Law requires that 20 per cent of the annual education budget should be allocated to vocational education and training. The system of fiscal decentralization in China and autonomy of the local governments significantly enhances the implementation of technical and vocational education, benefits local enterprises, due to the flexible TVET system that responds to local needs, as well as benefits the students in terms of employment. The local governments make appropriations for funding of TVET from locally generated revenue and provide such funds also for rural vocational training. As a matter of policy, local industries are required to utilize $1.5 \%$ of their payroll for in-service training. If the industries could not do this, they shall pay the equivalent in tax to the government to be disbursed for adult training. One major feature of the global scale rapid development in Chinese education system (including TVET) is the concept of "Key schools/educational institutions". The concept was applied at all the levels of education: basic, secondary and tertiary. As soon as the objectives were achieved, especially at the basic and secondary education level, the concept no longer operates in the basic and secondary education level because all the basic and secondary schools have become "key schools". The concept is currently still operating at the tertiary education level as the government intends to build more world class universities and train elite skilled manpower to drive the new policy of transforming to "new normal economy" which will see China transforming from a mere manufacturing base into innovationdriven economy, thereby changing the concept of "made in China" to "designed in China".

The concept of "key schools" started from the period of establishment of New China in 1949 and was stopped due to the Cultural Revolution. However, the concept was revived under the new administration of Deng Xiaoping from 1978. The concept was born out of the need to effectively utilize available scarce resources to develop the education sector. Faced with the dire challenges of shortage of skilled manpower to drive the growth of national economy and limited finances, the Chinese government decided to pool together available scarce resources to build key schools/institutions. It is well known that higher education plays significant role in providing highly skilled manpower for the development of any country, but the learners that will be recruited into the universities must be given proper education at the secondary school level. this informed the need to adopt the "key schools" concept at the secondary school level in China. In reviving the "key schools" concept, Deng Xiaoping emphasized the "need to have respect for knowledge and talents" and "if we want to achieve modernization, the key is lifting up science and technology; develop science and technology, it is imperative to firmly grasp education. It is impossible to achieve modernization by playing to the gallery, there must be knowledge and skilled talents. To firmly grasp science and technology, we must start from the primary school, secondary school and then the university. Education need two legs to walk: pay attention to it being universal and pay attention to quality. We must focus on building key primary schools, key secondary schools and key universities. We must gather excellent people into key secondary schools and key universities after going through thorough examination (Guoyou, 2015).

Technical and vocational education is under the control of the local governments and majority of the funding of technical and vocational education is provided by the local governments. The government takes care 
of about $71 \%$ of the entire expenditure on technical and vocational education through annual budgetary appropriations (Figure 6). According to the Vocational Education Law of 1996, the local governments at the village and county levels (i.e. sub-provincial level) have the responsibility to sponsor vocational education in schools and training institutions. Article 30 of the Law mandates the provincial governments, autonomous regions and municipalities to set aside funds for vocational education from the local charges they collect for education under the Education Law. The Law also specifies that the governments may appropriate funds for rural vocational training from the funds earmarked for developing agricultural science and technology. Provision was made in the Law to give tuition waiver for students in vocational education and training with financial difficulties or disability. Over 70 per cent of the funding for vocational schools at the secondary level comes from government finances, almost all of them by local governments. However, it is only in the case of Regular Specialized secondary schools and Technical schools (under MOHRSS) that the share of government finances is less than 70 per cent. These schools receive a greater proportion of funds from teaching, research and other supplementary sources.

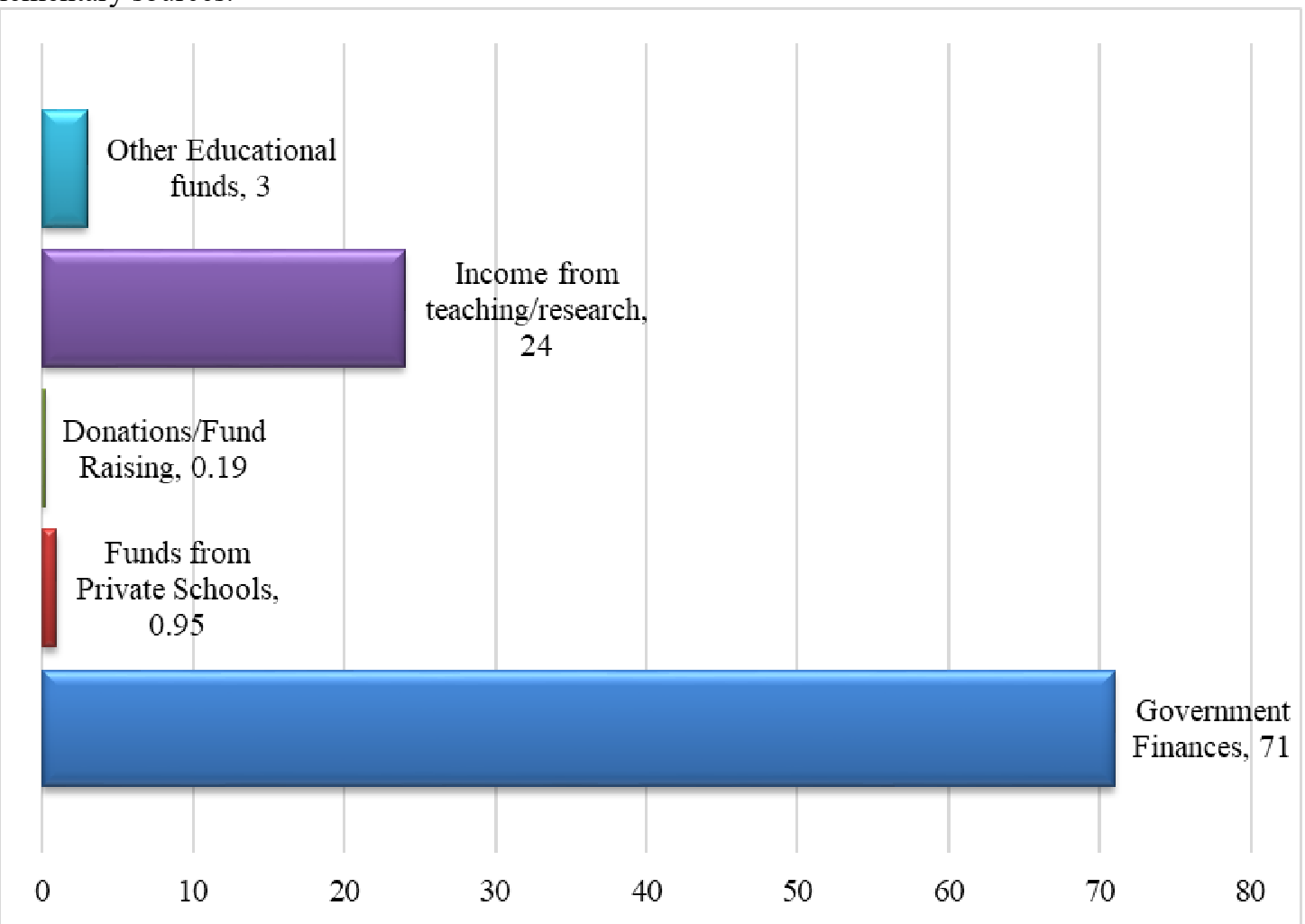

Figure 6: Source of TVET Funding in China (Ministry of Education PRC, 2015)

The main responsibilities for funding and administering TVET institutions moved from local governments at city levels at the first stage, to provincial/municipal governments at the second stage, to cooperation between local governments at provincial/municipal levels and city levels at the third stage, and now to governments at all levels - local governments at city levels, local government at provincial/municipal levels, and the central government. This indicates a trend of increasing support for TVET by the central government. The central government has emphasized multiple funding sources for TVET, such as government finance at different levels; industries, enterprises and employers; fundraising, tuition, school-run industries, education tax, loans, donations, and overseas funds providing room for multiple funding sources of TVET.

Furthermore, the central government encouraged diverse providers to run TVET institutions, which include local governments at city and provincial levels, industries and enterprises, non-government organizations, democratic parties, individuals, and foreign organizations/individuals. However, in the policy named Resolution on Energetically Developing Vocational Education, the State Council (2005) stresses that multiple funding sources for TVET should not change the dominance of the public ownership of TVET and "public vocational colleges should be main forces in developing vocational education" (para. 18).

Consequently, the government has played a role as the major provider for TVET institutions. Compared to local governments at provincial and city levels, however, the central government became involved later. By exerting macro management over TVET, the central government started to emphasize TVET practice at the second stage. At the third stage, the central government started to allocate special funds for TVET. At the fourth stage, the central government started to allocate significant funds for TVET. This process of involvement 
indicates that the central government has placed an increasing emphasis on developing TVET. Moreover, a dual internal governance system at TVET institutions is reflecting the strong leadership of the CPC. This has been a major means of ideological control in China.

China is not left out in the social stigma attached to TVET; in fact, the Chinese traditional education system is built on an elitist system where parents always want their children to go to regular academic schools in order for them to become government officials in future. However, faced with the dual challenge of need to provide skilled manpower to achieve the country's goal of industrialization and shortage of the required workforce to bring the goals into reality, the Chinese government adopted the provision of incentives to students to encourage the embrace of TVET. Apart from providing a tuition free TVET system, the government makes available monthly stipends for students enrolled in TVET schools. There are incentives to encourage students in agricultural vocational schools. Providing students with motivations to choose vocational stream in secondary high schools through the provision of stipend for rural students for boarding and lodging, as well as making tuition free of cost for all students has shown very positive outcomes for China's technical and vocational education with high employment rate of graduates of senior secondary vocational schools. Welfare programme for indigent students is a significant part of the education system and has gone through several reforms as the country develops. Zhu Jiade et al (2009) cited by Chen (2016) divided the changes in fee paying system, especially in secondary vocational education into four stages:

(1) The Full welfare phase (1949-1978)

(2) Transition from full welfare to market-oriented phase (1979-1984)

(3) Establishment of fee-paying system phase (1985-1996)

(4) Fee paying system fully formalized (beginning from 1996)

From the period of reform and opening up in the late 1970s, the Chinese government, guided by the principle of "efficiency and equity", placed special emphasis on provision of financial support to students of TVET, especially indigent female students who could not afford the costs of education. The financial support system has been fully developed over the years and is widely deployed in TVET institutions all over the country to guarantee that no student is left behind due to financial difficulties. Education reforms in the 1990s saw the introduction of fees in the post basic education sector (TVET belongs to this sector) and it became increasingly difficult for students from poor households to complete their studies without government's financial support due to limited finance. As the country faced the reality of the significance of TVET in the education sector, especially in meeting the need of the country's rapidly expanding industrialization development, by providing platform for training the required skilled manpower on one hand and the challenge of low status of TVET in the country with parents having high preference for university education, the country needed to come up with a policy to support the development of TVET. The 1996 Vocational Education Law of China was promulgated and made provisions for scholarship funds, bursary, prize awards for excellence and financial aid for indigent students.

Over the years, the implementation of financial aid to students of TVET institution has taken various forms and by 2010, secondary technical and vocational education in the country is tuition free with financial aid to students. The policy has impacted significantly on the student enrolment in secondary technical and vocational schools in the country. Between 2006 and 2011, close to 7.5million TVET students received financial aid from the government, with more than 100billion Yuan committed by the government. Fiscal input from the government is the mainstay of TVET funding in China. According to Chen (2016), the financial aid policy to students is implemented in three areas:

a. Bursary

This is provided for full-time TVET students in the first and second year of study. The bursary is paid directly into the beneficiary's bank account and is tax exempted. The students receive 125 yuan (about \$20) monthly amounting to is 1500 yuan (about \$240) per year. The fund comes from the central and regional governments based on agreed proportions considering the financial capacities of the regional governments. In less developed regions of the country, the central government takes full responsibility for the disbursement of funds for bursary.

\section{b. Free Tuition Programme}

It is believed that the cost of running a TVET institution is higher than that of a regular academic institution due to the cost of acquiring and maintaining training equipment. This informed the reason why TVET institutions charge tuition fees from students. Having considered the significant role of TVET in economic development of the country, and to reduce the financial burden of learners, the Chinese government made the decision that all public owned secondary technical and vocational schools will be tuition free for full-time students from the first to the final year of study. Between 2009-2011, a total of 12.61million students have benefitted from the free tuition policy and a total of about 20.96billion yuan (about \$3billion). The standard tuition fee is about 2000yuan (about \$310) per student per annum. 
Table 4: Bursary and Free Tuition Programme in Specialized Vocational Education (SVEs)- 2009-2011

\begin{tabular}{|l|l|l|l|}
\hline & $\mathbf{2 0 0 9}$ & $\mathbf{2 0 1 0}$ & $\mathbf{2 0 1 1}$ \\
\hline Beneficiaries & $4,260,000$ & $4,400,000$ & $3,950,000$ \\
\hline Amount & $4,260,000,000$ & $8,800,000,000$ & $7,900,000,000$ \\
\hline
\end{tabular}

Source: (Chen, 2016)

c. Other Financial Aid

These include scholarships provided by individual schools, free tuition by individual schools, internship, apprenticeship and so on. Groups in the society, enterprises and individuals also provide financial aid for schools and indigent students.

\section{Summary and Conclusion}

There is need to carry out reforms with the intention to make the TVET systems in Nigeria more responsive to the demands of labour market, trainee needs and expectations, and to make them more efficient and effective within the context of the limited resources available to the government. The increasing global demand for international competitiveness, flexibility and innovativeness, as well as greater skills and flexibility from the labour force, calls for strategic funding of TVET system in Nigeria to meet this demand. Nigeria's intention of ensuring the country has the desired trained labour force in the face of changing world of work is realizable if the nexus between TVET and skills development is adequately harnessed by effectively integrating skills and knowledge acquisition program into the country's post-basic education system as investing in knowledge and skills is seen by many governments as the cornerstone of developing an employable and globally competitive work force (AFDB \& OECD, 2008). All young people require skills that prepare them for decent jobs, so they can thrive and participate fully in their societies.

Quality education and skills not only empower the recipients for access to economically and socially rewarding jobs, but also empower them to create jobs, provide opportunities for re-integration of displaced workers and migrants and provide platform for school drop-outs and graduates to transit from school to work. Developing relevant skills and competencies among the youth, poor and vulnerable members of the society is crucial to reducing poverty and poverty-triggered insecurity in Nigeria. This becomes imperative as skills development in the global community is not just a part of a country's human resources strategies, but more of economic growth, poverty reduction and national security strategies.

Amid the constantly changing, knowledge driven global world of work, a coordinated strategy to boost labour demand and supply for the promotion of flexible employment growth and quality of jobs in Nigeria through the platform of education for skills is a national priority. Investment in education for skills as well as basic health and social protection will empower people to move out of poverty, equip people to be socially mobile and to avoid exclusion, as well as improve resilience for both individuals and society as a whole (AFDB, OECD, \& UNDP, 2017). To ensure inclusive growth among individuals and the society at large, there must be a blend between investment in skills and knowledge along with monetary stimulus measures, updated business practice, infrastructures, efficient markets and investment in innovation which are key components for driving sustained growth and prosperity (WEF, AFDB, \& World Bank Group, 2017).

TVET competes for limited resources, particularly public resources, in developing countries; it is important therefore to ensure that every allocated resource to TVET is effectively utilized within the highest form of monitoring and evaluation. The "key school" programme adopted by the Chinese during the time of scarce resources could be adopted by Nigeria in ensuring that available scarce resources re pooled together to achieve effectiveness in funding of TVET delivery in the country. This is imperative knowing that a good TVET may bring about positive impacts, while poor TVET will not, in which case, limited public and private resources might have been avoidably squandered.

\section{References}

AfDB. (2014). African Development Bank Human Capital Strategy 2014-2018, (May), 1-52.

AFDB, \& OECD. (2008). African Economic Outlook 2008.

AFDB, OECD, \& UNDP. (2017). African Economic Outlook 2017. Abidjan. https://doi.org/10.1787/aeo-2017en

Afeti, G. (2009). Technical and vocational education and training for industrialization. Retrieved August 30, 2017, from http://scholar.google.co.za/scholar?hl=en\&q=Technical+and+Vocational+Education+ and + Training+for+Industrialization\&btnG $=\&$ as_sdt $=1 \% 2 \mathrm{C} 5 \&$ as_sdtp

Atchoarena, D. (2009). Overview: Issues and Options in Financing Technical and Vocational Education and Training. In International Handbook of Education for the Changing World of Work (pp. 1029-1036). Dordrecht: Springer Netherlands. https://doi.org/10.1007/978-1-4020-5281-1_68

Bennell, P., \& Segerstrom, J. (1998). Vocational education and training in developing countries: has the World 
Bank got it right? International Journal of Educational Development, 18(4), 271-287. https://doi.org/10.1016/S0738-0593(98)00021-2

Billett, S. (2011). Vocational Education. Dordrecht: Springer Netherlands. https://doi.org/10.1007/978-94-0071954-5

Chen, M. (2016). 中国职业教育改革与发展实践 Practice of Reform and Development of Vocational Education in China. (L. Hongwu, Ed.) (1st ed.). Shenyang: Liaoning Education Publishers.

Dike, V. E. (2009). Addressing Youth Unemployment and Poverty in Nigeria: A Call for Action, not Rhetoric. Journal of Sustainable Development in Africa (Volume 11, No.3, 2009), 11(3), 129-151.

Federal Ministry of Education Nigeria. (2007). Federal Ministry of Education 10 Year Strategic Plan.

Federal Ministry of Education Nigeria. (2009a). Report of the Vision 2020 National Technical Working Group On Education Sector.

Federal Ministry of Education Nigeria. (2009b). Roadmap for the Nigerian Education Sector.

Federal Minstry of Education Nigeria. (2005). Nigeria Education Sector Diagnosis: A Framework for Reengineering the Education Sector.

Gabadeen, W. O., \& Raimi, L. (2012). Management of Entrepreneurship Education in Nigerian Higher Institutions: Issues, Challenges and Way Forward. Abuja International Journal of Education and Management Sciences, 2, 1-26.

Guo, Z., \& Lamb, S. (2010). International Comparisons of China's Technical and Vocational Education and Training System (Vol. 12). Dordrecht: Springer Netherlands. https://doi.org/10.1007/978-90-481-8743-0

Guoyou, W. (2015). The Period of Deng Xiaoping's Reformation. (M. Nestor, Ed.) (1st ed.). Beijing: Foreign Languages Press Co. Ltd. Beijing. Retrieved from http://www.flp.com.cn

IBRD, \& World Bank. (2015). More, and More Productive, Jobs for Nigeria : A Profile of Work and Workers. Retrieved from www.worldbank.org

Idris, A., Rajuddin, M. R., Bin, A., Latib, A., Udin, A. Bin, Sukri, M., ... Buntat, Y. Bin. (2012). Implementation of Technical and Vocational Education in Post- Primary Schools in Nigeria: A Qualitative Approach. International Journal of Humanities and Social Science Invention ISSN (Online, 1(1), $2319-7722$. Retrieved from http://www.ijhssi.org/papers/v1(1)/Version-2/E113033.pdf

ILO. (2015). Binding Constraints to Inclusive and Job-Rich Growth in Nigeria: A Review of Macro and Sector Policies and Strategies. Nigeria. Retrieved from www.ilo.org/publns

Inyiagu, E. E. (2014). Challenges facing technical and vocational education in Nigeria. Journal of Educational Policy and Entrepreneural Research, 1(1), 40-45. Retrieved from www.iiste.org

Johanson, R. (2009). Review of National Training Fund (No. 0922). Social Protection (SP) Discussion Paper.

Johansson, D., Adams, A. V., \& Sara Razmara, S. (2013). Improving Skills Development in the Informal Sector. The World Bank. https://doi.org/10.1596/978-0-8213-9968-2

Joshua A. Bello. (2005). Fiscal Policy and the Growth of Foreign Direct Investment in Sub-Saharan Africa (Selected Countries: Ghana, Kenya, Nigeria, and South Africa). Retrieved from https://etd.auburn.edu/bitstream/handle/10415/229/BELLO_JOSHUA_7.pdf;sequence=1

Kenneth King \& Robert Palmer. (2010). Planning for technical ä vocational skills development. UNESCO:international Institute for Educational Planning. https://doi.org/10.1007/s11159-013-9345-5

Kingombe, C. (2012). Lessons for Developing Countries from Experience with Technical and Vocational Education and Training. International Growth Centre. Retrieved from www.theigc.org

Ladipo, M. K., Akhuemonkhan, I. A., \& Raimi, L. (2013). Technical and Vocational Education and Training As a Mechanism for Sustainable Development in Nigeria: Potentials, Challenges and Policy Prescriptions. Vocational and Technical Education in China, 4(1), 52-67. Retrieved from www.cctve.com.cn

Maclean, R., \& Wilson, D. (Eds.). (2009). International Handbook of Education for the Changing World of Work. Dordrecht: Springer Netherlands. https://doi.org/10.1007/978-1-4020-5281-1

Middleton, J., Ziderman, A., \& Adams, A. Van. (1996). SKILLS FOR PRODUCTIVITY: VOCATIONAL EDUCATION AND TRAINING IN DEVELOPING COUNTRIES.

Ministry of Education PRC. (2015). 中国教育年鉴China Education Yearbook 2015. (宋德民 \& 李曜升, Eds.) (1st ed.). Beijing: 人民教育出版社. Retrieved from http://www.pep.com.cn

National Bureau of Statistics. (2016a). Unemployment / Under-Employment Watch Q1 2016, (May), 15. Retrieved from http://www.nigerianstat.gov.ng/report/397

National Bureau of Statistics. (2016b). Unemployment / Under - Employment Report Q4 2015.

National Bureau of Statistics. (2017). Nigeria Annual Abstract of Statistics (Vol. 2). Retrieved from http://www.nigerianstat.gov.ng/pdfuploads/annual_abstract_2012.pdf

NISER. (2009). Study on Skills Development for the Informal Sector of the Nigerian Economy (Vol. 29). Retrieved from http://www.journals.cambridge.org/abstract_S0001972000060666

Obanya, P. (1996). The development of technical and vocational education in Africa.

Odu, K. (2010). Skills acquisition in Nigerian education system: problems and prospects in technical education. 
Journal of Qualitative Education, 6(1), 20-26.

OECD. (2004). OECD Handbook for Internationally Comparative Education Statistics. OECD Publishing. https://doi.org/10.1787/9789264104112-en

OECD. (2015). OECD Skills Outlook 2015. OECD Publishing. https://doi.org/10.1787/9789264234178-en

Oketch, M. (2014). Education policy, vocational training, and the youth in Sub-Saharan Africa, (March), 18. Retrieved from http://www.wider.unu.edu/stc/repec/pdfs/wp2014/WP2014069.pdf\%5Cnhttp://search.ebscohost.com/login.aspx?direct=true\&db=ecn\&AN=1466524\&site=ehost-live

Okoye, K. R. E., \& Udoudo, E. E. (2015). Vocationalisation of Secondary Education in Nigeria: Issues , Challenges and Prospects. Journal of Education and Practice, 6(30), 71-76. Retrieved from www.iiste.org

Psacharopoulos, G. (1990). Why educational policies can fail: an overview of selected African experiences. World Bank Discussion Papers (Vol. 82).

Radwan, I., \& Pellegrini, G. (2010). Knowledge, Productivity and Innovation in Nigeria. https://doi.org/10.1596/978-0-8213-8196-0

Uddin, P. S. O., \& Uddin, O. O. (2013). Article information :Causes, effects and solutions to youth unemployment problems in Nigeria. Journal of Emerging Trends in Economics and Management Sciences, 4(4), 397-402. Retrieved from http://reference.sabinet.co.za/webx/access/electronic_journals/sl_jetems/sl_jetems_v4_n4_a4.pdf

UNESCO-IIEP. (1996). Financing technical and vocational education : modalities and experiences.

UNESCO. (2012). ESD + TVET: Promoting Skills for Sustainable Development. Retrieved from www.unesco.org/education

UNESCO. (2016). Strategy for Technical and Vocational Education and Training (TVET), (2016-2021). Unesco. Retrieved from www.unesco.org/education

WEF, AFDB, \& World Bank Group. (2017). The Africa Competitiveness Report 2017 - Addressing Africa's Demographic Dividend. Geneva. Retrieved from http:/www.weforum.org/en/initiatives/gcp/Global Competitiveness Report/index.htm 